DOI 10.4467/25439561KSR.21.003.14414

JANUSZ SMOŁUCHA (D https://orcid.org/0000-0003-2633-7093

Akademia Ignatianum

Kraków

\title{
IDEA JEDNOŚCI SŁOWIAŃSKIEJ W DZIAŁALNOŚCI DYPLOMATYCZNEJ W EUROPIE ŚRODKOWO-WSCHODNIEJ NUNCJUSZA PAPIESKIEGO ALEKSANDRA KOMULOVICIA W LATACH 1594-1597
}

\author{
THE IDEA OF SLAVIC UNITY IN THE DIPLOMACY \\ OF ALEXANDER KOMULOVIĆ, THE PAPAL NUNCIO \\ TO CENTRAL AND EASTERN EUROPE IN 1594-1597
}

\section{Streszczenie}

Gdy w 1593 roku wybuchła kolejna wojna austriacko-turecka, papież Klemens VIII rozpoczął budowanie Ligi Świętej, złożonej głównie z państw Europy Środkowej i Wschodniej, która miała się przeciwstawić kolejnej agresji ze strony muzułmanów. Ze swoich planów kuria rzymska nie wyłączała Moskwy. Ideę bliskiej z nią współpracy pozostałych państw słowiańskich głosił w tamtym czasie pochodzący z Dalmacji duchowny i dyplomata papieski, Aleksander Komulović. Autor postarał się zrekonstruować misję dyplomatyczną Komulovicia do Europy Środkowo-Wschodniej w latach 1594-1597 wraz z oceną szans jej powodzenia w ówczesnych warunkach religijnych i geopolitycznych.

\section{Abstract}

The outbreak of another Austro-Turkish war in 1593, urged Pope Clement VIII to establish the Holy League which mainly consisted of the Central and Eastern European states, and the aim of which was to oppose another Muslim aggression against Christians. The Roman Curia decided to include Muscovy in the plan as well. The idea of close cooperation 
with all Slavic states was put forward at that time by Aleksander Komulović - a priest and papal diplomat from Dalmatia. The author's aim was to reconstruct the Komulović's diplomatic mission to Central and Eastern Europe in 1594-1597, and provide an assessment of the chances of its success in the light of religious and geopolitical underpinnings of the period.

Słowa kluczowe: papiestwo, Rzeczpospolita Obojga Narodów, Moskwa, Słowianie, dyplomacja papieska, Turcja, Liga Święta

Key words: papacy, Polish-Lithuanian Commonwealth, Muscovy, the Slavs, papal diplomacy, Turkey, the Holy League

Wraz z postępującym rozpadem jedności chrześcijańskiej, w 2. połowie XVI wieku, jednym z najważniejszych sojuszników papiestwa stała się Rzeczpospolita Obojga Narodów ${ }^{1}$. Stolica Apostolska starała się w taki sposób oddziaływać na kierunki polityki polsko-litewskiego państwa, aby nie naruszając wzajemnych relacji, uwzględniały one również jej interesy. Poza kwestią wyznaniową na pierwszy plan zaczęła wysuwać się kwestia obrony przed ekspansją Turków osmańskich ${ }^{2}$. Niebezpieczeństwo tureckie absorbowało politykę europejską już od połowy XIV wieku. Z powodu słabości władzy cesarskiej pod koniec wieków średnich koordynacja działań obronnych została przejęta przez papiestwo i kurię rzymską. Niewiele pod tym względem zmieniło się w epoce nowożytnej. Odpowiadając na agresywne działania Turków we wschodnim obszarze Morza Śródziemnego, papież Pius V zorganizował w 1571 roku wśród państw chrześcijańskich Ligę Świętą, w której główną rolę odgrywały Hiszpania i Wenecja. Jej działania zakończyły się wielkim triumfem - zwycięstwem w bitwie morskiej pod Lepanto. Ponieważ zagrożenie tureckie w następnych dziesięcioleciach nie ustawało, a nawet zaczęło przybierać na sile, kolejni papieże również zabiegali o tworzenie podobnych Lig Świętych, do których zachęcali państwa katolickie. Z czasem do antytureckiego porozumienia zaczęto zapraszać również Moskwę. Spotkało się to jednak z zastrzeżeniami strony polskiej, która postrzegała w niej rywala dla swoich interesów na Wschodzie. Nie zważając na pojawiające się protesty, dyplomacja Stolicy Apostolskiej coraz aktywniej zaczę-

${ }^{1}$ Przyczyną geopolitycznych zmian w nowożytnej Europie była reformacja, która, choć zyskała w Rzeczypospolitej wielu zwolenników, nie zdominowała katolicyzmu. Podtrzymywanie ścisłych związków z Rzymem i trwanie przy tradycyjnym wyznaniu stało się racją stanu dla zdecydowanej większości szlachty. Postawę tę wspierali kolejni władcy elekcyjni, w tym zasiadający na tronie krakowskim od 1587 r. Zygmunt III Waza. Papieże chcąc docenić tę postawę i podnieść międzynarodową rangę Rzeczypospolitej zaczęli nazywać ją „przedmurzem chrześcijaństwa” i „chlubą Północy”, zob. H. Litwin, Chwała Pólnocy. Rzeczpospolita w polityce Stolicy Apostolskiej w pierwszej polowie XVII wieku (1598-1648), Lublin, Wydawnictwo KUL, 2013, s. 301.

${ }^{2}$ Ostatnio na ten temat zob. D. Gregorowicz, Tiara w grze o korone. Stolica Apostolska wobec wolnych elekcji w Rzeczypospolitej Obojga Narodów w drugiej połowie XVI wieku, Kraków, Polska Akademia Umiejętności, 2019, ss. 57-69. 
ła działać na tamtym terenie. Jednym z najlepszych tego przykładów była wyprawa do Moskwy, jaką w latach 1581-1582 odbył na polecenie Grzegorza XIII włoski jezuita Antonio Possevino ${ }^{3}$. Mniej znanym epizodem zabiegów Stolicy Apostolskiej o nawiązanie bliskiej współpracy z Moskwą były późniejsze o dekadę zabiegi chorwackiego księdza i papieskiego dyplomaty, Aleksandra Komulovicia. W artykule dokonano na podstawie dostępnych źródeł i literatury przedmiotu analizy misji dyplomatycznej, jaką odbył on w latach 1594-1597 w celu próby zbudowania sojuszu antytureckiego w oparciu o współpracę różnych narodów słowiańskich.

Aleksander Komulović urodził się w 1548 roku w Splicie - mieście położonym w Dalmacji weneckiej, w średnio bogatej rodzinie mieszczańskiej. O jego wczesnej edukacji niewiele wiadomo, wstępne wykształcenie zdobył prawdopodobnie w przykatedralnej szkole w rodzinnym mieście. Nie znamy dokładnej daty jego święceń kapłańskich, ale wiemy, że w 1572 roku został on mianowany członkiem kapituły katedralnej w Splicie ${ }^{4}$. Nie wiadomo też, kiedy dokładnie Komulović przyjechał po raz pierwszy do Rzymu. Pewne jest to, że w 1576 roku został członkiem Konfraterni Św. Hieronima przy znajdującym się nad Tybrem Hospicjum Iliryjskim. Niedługo potem Komulović podjął studia w jezuickim Kolegium Rzymskim. W 1579 roku wstapił na służbę kardynała Giulia Antonia Santorio, odpowiedzialnego za sprawy Kościołów wschodnich i protektora „Iliryjczyków”. W ramach swoich obowiązków Komulović zajmował się sprawami swojej rodzinnej Dalmacji, ale utrzymywał przy tym również kontakty z chrześcijanami zamieszkującymi tereny pod rządami Turków5.

W 1584 roku Grzegorz XIII wyznaczył Komulovicia, wraz z jezuitą Tommaso Raggio, apostolskimi wizytatorami na europejskim obszarze imperium tureckiego. Celem papieskich wysłanników było wdrożenie dekretów soboru trydenckiego odnoszących się szczególnie do zmian w liturgii i dyscypliny duchowieństwa ${ }^{6}$. Znane jest ich, sporządzone w Sofii pod koniec listopada 1584 roku, sprawozdanie z wizytacji

${ }^{3}$ Zob. J. Smołucha, Uwagi na temat kwestii tureckiej $w$ działalności dyplomatycznej $i$ naukowej ojca Antonia Possevino, [w:] Antonio Possevino SJ (1533-1611). Życie i dzieto na tle epoki, red. D. Quirini-Popławska, Kraków, WAM, 2012, ss. 545-562; J.J. Santich, Missio Moscovitica. The Role of the Jesuits in the Westernization of Russia, 1582-1869, New York, Peter Lang, 1995, ss. 85-111.

${ }^{4}$ Zob. P. Pierling, La Russie et le Saint-Siège. Études diplomatiques, t. 2, Paris, E. Plon, Nourrit et C ${ }^{\mathrm{ie}}$, 1897, s. 333; F. Pignatti, Komulović Alexandar, [w:] Dizionario Biografico degli Italiani, t. 62, Rome, Istituto dell'Enciclopedia Italiana, 2004, ss. 757-759; Z. Zlatar, Our Kingdom Come. The Counter-Reformation, the Republic of Dubrovnik, and the Liberation of the Balkan Slavs, New York 1992, Columbia University Press, s. 206; A. Trstenjak, Alessandro Komulovic S.I., 1548-1608. Profilo biografico, „Archivum Historicum Societatis Iesu”, 58 (1989), ss. 43-44.

${ }^{5}$ Zob. P. Pierling, F. Rački, L. Komolovica izvještaj i listovi o poslanstvo njegovu u Torsku, Erdelj, Moldavsku i Poljsku, „Starine” 1882, t. 14, ss. 83-84; A. Trstenjak, Alessandro Komulovic S.I...., op.cit., ss. 45-47.

${ }^{6}$ P. Pierling, Novi izvori o L. Komuloviću, „Starine”, 1884, t. 16, ss. 210-219; A. Trstenjak, Alessandro Komulovic S.I...., op.cit., ss. 48-49; O. Halecki, The Renaissance Origin of Panslavism, „The Polish Review" 1958, t. 3, nr 1/2, s. 14. 
prowincji Macedonii, Serbii i Bułgarii, w którym to poinformowali oni Rzym, że we wszystkich tych miejscach natrafili na wyznawców chrześcijaństwa. Większość z nich była Słowianami, którzy pomimo licznych przeszkód starali się zachować wiarę i oparte na tradycji życie duchowe ${ }^{7}$. Komulović, już w swoim imieniu, wysłał do kurii rzymskiej osobny list, w którym po raz pierwszy wyraził swoje poglądy na temat sytuacji Słowian na terenach podbitych przez Turków. Jego zdaniem pojawiły się szanse na zrzucenie przez nich uciążliwego jarzma. Donosił, że z powodu przeciagającej się wojny z Persami Turcy wycofali niedawno większość swoich sił militarnych z europejskiej części imperium i pozostawili cały kraj prawie bez obrony. Ponadto ludność imperium tureckiego zdziesiątkowana została przez ciężką epidemię. Papieski wysłannik proponował wykorzystać okazję i zorganizować ligę państw chrześcijańskich, której celem byłoby uderzenie na osłabionych wrogów. Przekonywał, iż zaistniała wówczas okazja, aby wyprzeć Turków z Europy, „stanąć na murach Konstantynopola, a nawet odbić Ziemię Świętą".

Nie wiadomo, jak list ten został przyjęty w kurii rzymskiej. Można się tylko domyślać, że pod koniec rządów Grzegorza XIII propozycje Komulovicia miały niewielką szansę na realizację. Nadzieję przyniosła dopiero zmiana na tronie Piotrowym, gdy w kwietniu 1585 roku zasiadł na niej Felice Peretti jako Sykstus V9. Nowy papież urodził się i wychował w regionie Marche, w leżącej nad Adriatykiem historycznej Picenii, gdzie położone jest Loreto - słynne sanktuarium maryjne. W okolicy tego miejsca osiedliło się wiele słowiańskich rodzin - uciekinierów z Dalmacji, którzy w obawie przed Turkami przenieśli się na drugą stronę Adriatyku. Jak głosiła ówczesna fama, papież Sykstus V wywodził się z jednej z nich ${ }^{10}$.

Pontyfikat Sykstusa V otworzył przed Komuloviciem olbrzymią szansę na realizację jego dyplomatycznych i politycznych planów. Licząc na zrozumienie u papieża, ugruntował tezę o pierwszorzędnej roli, jaką w niedalekiej przyszłości odegrają narody słowiańskie, stając w obronie chrześcijańskiej wiary i cywilizacji. Według Komulovicia Słowianie tworzyli tak naprawdę jeden naród i posługiwali się jedynie dia-

${ }^{7}$ Zob. P. Pierling, Novi izvori o L. Komuloviću, op.cit., ss. 219-220; Acta Bosnae potissimum ecclesiastica cum insertis editorum documentorum regestis ab anno 925 usque ad annum 1752, red. E. Fermendžin, Zagreb, Taberna libraria, 1892, ss. 339-340.

${ }^{8}$ Acta Bosnae potissimum ecclesiastica ..., op.cit., ss. 337-338; A. Trstenjak, Alessandro Komulovic S.I..., op.cit., s. 50.

${ }^{9}$ Zob. L. Pastor, Storia dei papi, t. 10, Roma, Desclée \& C.Editori Pontifici, 1928, s. 20 i n.

${ }^{10}$ Sykstus V przez cały pontyfikat okazywał dużą życzliwość Słowianom. Otaczał też opieką Dom Nazaretański w Loreto, który według legendy po zabraniu z Palestyny pod koniec XIII w., zanim trafił do regionu Marche, przez pewien czas znajdował się we Fiume (obecnie Rijeka) na Półwyspie Istria. Przy sanktuarium w Loreto funkcjonowało bractwo iliryjskie, które podtrzymywało więzi ze Słowianami żyjącymi po drugiej stronie Adriatyku, zob. F. Coltrinari, Loreto as an Illyrian Shrine. The Artistic Heritage of the Illyrian Confraternities and College in Loreto and Recanati, „Confraternitas”, 2016, t. 27, nr 1-2, ss. 46-61; K. Velez, The Miraculous Flying House of Loreto: Spreading Catholicism in the Early Modern World, Princeton, Princeton University Press, 2019, s. 48. 
lektami tego samego języka. $Z$ tego też powodu powinni dążyć do jedności państwowej, a nawet wyznawania tej samej religii - katolicyzmu ${ }^{11}$. W przygotowanym dla Sykstusa V obszernym memorandum na ten temat Komulović wspomniał, że w trakcie niedawnej misji w imperium tureckim zdobył wystarczającą wiedzę o ciężkim położeniu tamtejszych chrześcijan, aby szukać obecnie dla nich najlepszego rozwiązania. Był przekonany o ich gotowości do buntu i antymuzułmańskiego powstania. Warunkiem jego powodzenia byłojednak wsparcie zzewnątrz.Zdaniem Komulovicia, Stolica Apostolska wykorzystując swoją sieć powiązań dyplomatycznych, powinna zainicjować działania na rzecz udzielenia im politycznej i militarnej pomocy. Na wypadek wojny z Turkami podawał rozwiązania logistyczne, w tym liczbę potrzebnych żołnierzy, rodzaje sił zbrojnych, a nawet taktykę bojową. Twierdził jednak, że aby skutecznie wyprzeć Turków z Europy nie wystarczy wsparcie samych krajów katolickich. Trzeba było zwrócić się również o pomoc Moskwy. Był przekonany, że z jej udziałem chrześcijańskie wojska szybko dotrą do bram samego Kostantynopola ${ }^{12}$.

Z misji na Bałkany Komulović wrócił do Wiecznego Miasta w kwietniu 1587 roku Zamieszkał w hospicjum przy parafii Św. Hieronima nad Tybrem, gdzie powierzono mu funkcję spowiednika. Dwa lata później został wybrany rektorem tamtejszego Bractwa Św. Hieronima. W tamtym czasie pozostawał w ścisłych relacjach z Sykstusem V i jego najbliższym otoczeniem. Świadczy o tym między innymi fakt, iż papież wsparł finansowo bardzo kosztowną przebudowę kościoła św. Hieronima i jego otoczenia ${ }^{13}$. W archiwach papieskich zachowała się zapiska mówiąca o tym, że Syktus V zamierzał przenieść tam księży z Kolegium Iliryjskiego z Loreto. Jest niezwykle interesujące, że wolą tego papieża było dołączenie do niego podobnego kolegium polskiego. Pragnął on stworzyć w Rzymie pansłowiańskie centrum formacji duchownych katolickich, a argumentem za tym połączeniem miało być bliskie podobieństwo ludów słowiańskich ${ }^{14}$. Plany te nie zostały zrealizowane w związku

${ }^{11}$ Zob. Z. Zlatar, Our Kingdom Come..., op.cit. s. 180; J.V.A. Fine, When Ethnicity Did Not Matter in the Balkans, Ann Arbor, University of Michigan Press, 2006, s. 235.

${ }^{12}$ Zob. A. Trstenjak, Alessandro Komulovic S.I..., op.cit., ss. 50-51.

${ }^{13}$ Prace przy świątyni trwały w latach $1588-1589$ i zostały w całości sfinansowane Sykstusa V. W Bibliotece Watykańskiej zachował się datowany na 1590 r., sygnowany m.in. przez Komulovicia, szczegółowy inwentarz konfraternii i kościoła św. Hieronima z okresu tej przebudowy, zob. Biblioteca Apostolica Vaticana, Vat. Lat. 5440, 1r-12r; J. Gudelj, San Girolamo dei Croati a Roma. Gli Schiavoni e il cantiere sistino, [w:] Identità e rappresentazione. Le chiese nazionali a Roma, 1450-1650, red. A. Koller, S. Kubersky-Piredda, Roma, Campisano Editore, 2015, ss. 316-317.

${ }^{14}$, ,.... questi nationi sono poco dissimili l'una dall' altra”, zob. Biblioteca Apostolica Vaticana, Urb. lat. 1057, f. 635v; L. Pastor, Storia dei papi, t. 10, ss. 617-618; J. Gudelj, The Hospital and Church of the Schiavoni/Illyrian Confraternity in Early Modern Rome, „Confraternitas”, 27/1-2 (2016), s. 12. Kolegium Iliryjskie w Loreto zostało założone w 1580 r. przez papieża Grzegorza XIII. Było ono utrzymywane z dochodów miejscowych kanoników, a prowadzone przez jezuitów. Kolegium przygotowywało do pracy misyjnej w Dalmacji i na sąsiadujących z nią terenach zamieszkałych przez Słowian, zob. F. Coltrinari, Loreto as an Illyrian Shrine..., op.cit., ss. 54-55. 
z nieoczekiwaną śmiercią Sykstusa V, będącej skutkiem wysokiej gorączki spowodowanej malarią (27 sierpnia $1590 \mathrm{roku})^{15}$.

O słowiańskich projektach Aleksandra Komulovicia przypomniano sobie w kurii rzymskiej dopiero wiosną 1593 roku, gdy w nową fazę wszedł konflikt austriacko-turecki ${ }^{16}$. Na tronie papieskim zasiadał wówczas Hipolit Aldobrandini jako Klemens VIII ${ }^{17}$. Na tle swoich poprzedników papież ten wybijał się nie tylko siłą charakteru, ale także roztropnością i rozległą wiedzą o świecie. Jako kardynał odbył kilka ważnych misji dyplomatycznych, z których najsłynniejszą była legacja do Królestwa Polskiego w latach 1588-1589. Miała on na celu zapośredniczenie pokoju w sporze o krakowski tron między Zygmuntem III Wazą a arcyksięciem Maksymilianem Habsburgiem. Misja ta okazała się być dla kardynała Aldobrandiniego doskonałą okazją do zaznajomienia się z religijnymi i politycznymi realiami Europy Środkowej i Wschodniej ${ }^{18}$.

Klemens VIII swoją przywódczą rolę w świecie chrześcijańskim nie ograniczał jedynie do spraw duchowych. Wzorując się na swoich wielkich poprzednikach z doby krucjat, zabiegał na arenie międzynarodowej o udzielenie wsparcia dla idei wojny sprawiedliwej w obronie chrześcijańskiej wiary i cywilizacji ${ }^{19}$. Wezwanie o dołączenie do antytureckiej Ligi Świętej zostało skierowane również do polskiego króla Zygmunta III Wazy ${ }^{20}$. Aby dać monarchom przykład, papież nie ograniczył się jedynie do działań dyplomatycznych, ale z własnych środków sformował kilkutysięczną armię zaciężną i wysłał ją na węgierski teatr wojenny ${ }^{21}$.

Dla uważnych obserwatorów nadzwyczajne działania papieskie miały swoje uzasadnienie w pogarszającej się z dnia na dzień sytuacji geopolitycznej. Wieść o wybuchu nowej wojny austriacko-tureckiej wzbudził nad Tybrem wiele obaw i niepokojów. Były one dodatkowo wzmacniane przez raporty nuncjusza papieskiego w Pradze Cesare Speciano. Donosił on, że ekscentryczny i cierpiący na depresję Rudolf II nie

${ }^{15}$ Zob. L. Pastor, Storia dei papi, t. 10, op.cit, s. 408.

${ }^{16}$ Zob. K.M. Setton, Venice, Austria, and the Turks in the Seventeenth Century, Philadelphia, American Philosophical Society, 1991, ss. 8-22; J.P. Niederkorn, Die europäischen Mächte und der "Lange Türkenkrieg” Kaiser Rudolfs II. (1593-1606), Wien, Verlag der Österreichischen Akademie der Wissenschaften, 1993.

${ }^{17}$ Zob. L. Pastor, Storia dei papi, t. 11, Roma, Desclée \& C.Editori Pontifici, 1929, s. 16.

${ }^{18}$ Zob. D. Gregorowicz, Tiara w grze o korone..., op.cit., ss. 191-211.

${ }^{19}$ Zob. P. Bartl, ,, Marciare verso Costantinopoli”-Zur Türkenpolitik Klemens 'VIII, „Saeculum”, 1969 , t. 20, s. 44.

${ }^{20}$ Zob. J. Sas, Układy o Lige przeciw Turkom za Zygmunta III, „Przegląd Powszechny” 1899 , t. 63 , ss. $56-57$.

${ }^{21} \mathrm{Na}$ czele tej armii postawił swojego nepota, Gianfrancesca Aldobrandiniego, zob. L. Pastor, Storia dei papi, t. 11, op.cit, ss. 210-211; K.M. Setton, Venice, Austria, and the Turks..., op.cit., ss. 1011; T. Kruppa, Pápai csapatok Magyarországon (1595-1597, 1601), Budapest - Roma, The Publishing House „Gondolat”, 2020, ss. XVI-XXVI. 
posiadał ani umiejętności, ani odwagi potrzebnej do powstrzymania tureckiej nawały. Według opinii nuncjusza, cesarza bardziej niż rządzenie interesowały sztuka, ezoteryka oraz magia. W cesarskim skarbcu brakowało pieniędzy na wypłatę dla żołnierzy, bo wydatkowano je na dziwaczne kaprysy monarchy. Na domiar złego ważne sprawy o wadze państwowej musiały tygodniami czekać na jego rozstrzygnięcie. W tej sytuacji było tylko kwestią czasu, kiedy pierwsze zagony tureckiego wojska pojawią się na przedpolach Wiednia ${ }^{22}$.

Istniało realne niebezpieczeństwo, że po zajęciu przez Turków Austrii nic nie stanie im na przeszkodzie, aby wkroczyć do Włoch. W tej sytuacji Klemens VIII postanowił bezzwłocznie przystapić do działania i nakazał swoim urzędnikom poszukiwać najlepszego rozwiązania. Powołanie pod auspicjami papieża Ligi Świętej z udziałem Hiszpanii i Wenecji, przy wsparciu państw z Europy Środkowej i Wschodniej - co od dawna proponował Komulović - wydawało się być dobrym pomysłem na zatrzymanie pochodu Turków do serca Europy ${ }^{23}$.

Gdy wiosną 1593 roku, rozważano w kurii rzymskiej te sprawy, Aleksander Komulović przygotowywał się do wstapienia do zakonu jezuitów w Loreto ${ }^{24}$. Plany te zostały przerwane niespodziewanymi decyzjami Klemensa VIII, który polecił mu udać się w randze nuncjusza apostolskiego do krajów Europy Środkowo-Wschodniej. Jego celem miała być agitacja na rzecz przyłączenia się do planowanej przez Stolicę Apostolską antytureckiej Ligi Świętej. Przygotowane dla Komulovicia pełnomocnictwa obejmowały zrazu Siedmiogród, Wołoszczyznę, Mołdawię oraz Rzeczpospolitą Obojga Narodów, potem dołączono również Moskwę. Przygotowując się do tej misji Komulović przez kilka miesięcy studiował kurialne dokumenty oraz prowadził konsultacje z papieskimi urzędnikami i doradcami ${ }^{25}$. Efektem tych prac była generalna instrukcja wystawiona dla Komulovicia 10 listopada 1593 roku. Zawarto w niej szczegółowy opis stawianych przed papieskim nuncjuszem celów i zadań. Zapisano

${ }^{22}$ Zob. listy nuncjusza Speciano do papieskiego Sekretariatu Stanu, 4 I 1593 - 4 XII 1593; N. Mosconi, La nunziatura di Praga di Cesare Speciano (1592-1598): nelle carte inedite vaticane e ambrosiane, t. 3, Brescia, Morcelliana, 1966, ss. 1-282. Na temat ezoterycznej atmosfery praskiego dworu cesarza Rudolfa II zob. P. Marshall, The Mercurial Emperor. The Magic Circle of Rudolf II in Renaissance Prague, London, Pimlico, 2007, ss. 185-198; V. Press, The Habsburg Court as Center of the Imperial Government, „The Journal of Modern History”, 1986, t. 58, ss. 33-34.

${ }^{23}$ Zob. L. Pastor, Storia dei papi, t. 11, op.cit., s. 202; T. Trstenjak, Aleksandar Komulović kao mogući uzor Jurju Križaniću u politici i crkvenom jedinstvu, „Zbornik Odsjeka za povijesne znanosti Zavoda za povijesne i društvene znanosti Hrvatske akademije znanosti i umjetnosti”, 1986, t. 14, s. 291.

${ }^{24}$ Zob. A. Trstenjak, Alessandro Komulovic S.I..., op.cit., s. 54.

${ }^{25}$ Ibidem, ss. 56-57. Papiescy dyplomaci zaczęli być w XVI w. starannie dobierani i przygotowywani. Zobowiązywano ich do składania częstych raportów i sprawozdań zarówno w trakcie pełnienia swoich misji, jak i po ich zakończeniu. Gwałtowny przyrost tych sprawozdań miał ścisły związek z ewolucją nuncjatur narodowych, która ustabilizowała się w odniesieniu do Rzeczypospolitej w 2. połowie XVI w., zob. D. Gregorowicz, Tiara w grze o koronę..., op.cit., ss. 50-69. 
w nim też alternatywne rozwiązania na wypadek zmieniających się sytuacji i nieprzewidzianych okoliczności ${ }^{26}$.

W instrukcji wskazano na wstępie powody, które skłoniły Stolicę Apostolską do wybrania do tej misji właśnie Komulovicia. Jak napisano, były nimi jego wiedza i doświadczenie oraz, co mocno podkreślono, znajomość języków słowiańskich. Urzędnikom kurialnym bardzo zależało na tym, aby pertraktacje prowadzone były bez obecności tłumaczy. W instrukcji dokonano krótkiej charakterystyki ludów słowiańskich pozostających pod panowaniem tureckim. Zwrócono uwagę na to, że większość z nich wyznawała co prawda chrześcijaństwo obrządku greckiego, ale nie była wrogo nastawiona do papieża. Według kurialistów, najbardziej wojowniczy i skłonni do zrzucenia tureckiego jarzma byli Serbowie. Inaczej natomiast wyglądała sprawa z Bułgarami. Jak mówił dokument, o wiele dłużej pozostawali oni pod rządami tureckimi i utracili bojowego ducha. Najważniejsze było jednak to, że udało im się wytrwać przy wierze chrześcijańskiej. Z Bułgarami układy należało prowadzić ostrożnie i tylko z osobami cieszącymi się dużym wśród nich autorytetem ${ }^{27}$. Podobnie papieski nuncjusz miał postępować w pertraktacjach z Kozakami. Tym bardziej, że jak wspomniano, Kozacy nie posiadali stałych przywódców i mieli zwyczaj wybierać ich, zależnie od okoliczności, spontanicznie. Radzono, aby w relacjach z nimi nuncjusz zachowywał najwyższą dyskrecję. Odnosiło się to zwłaszcza do planowanej przez Rzym unii Kościołów. Z powyższych powodów Komulović nie powinien przekazywać też szczegółów swych rozmów towarzyszącym mu pomocnikom $^{28}$.

Misja Komulovicia została bardzo precyzyjnie przygotowana. Jej szlak przebiegać miał przez Wenecję, gdzie zaplanowano spotkanie z przywódcami albańskich rebeliantów. Papieskiemu wysłannikowi polecono potajemnie negocjować z nimi możliwość wywołania w ich kraju antytureckiego powstania ${ }^{29}$. Z miasta nad lagunami szlak Komulovicia wiódł poprzez Trydent, Innsbruck i Wiedeń do Siedmiogrodu. Z tamtejszym księciem, Zygmuntem Batorym, miał omówić kwestię przystąpienia Siedmiogrodu do tworzonej przez papieża Ligi Świętej. Po drodze do Królestwa

${ }^{26}$ Zob. Biblioteca Apostolica Vaticana, Vat. lat. 13460, f. 414r-427r. Pełne, krytyczne wydanie instrukcji dla Aleksandra Komulovicia zob. Die Hauptinstruktionen Clemens' VIII. für die Nuntien und Legaten an den europäischen Fürstenhöfen (1592-1605), wyd. K. Jaitner, t. 1, Tübingen 1984, nr 30, ss. 186-204; E. Fermendžin, Prilozi k poznavanju diplomatskoga poslanstva Aleksandra Komulovića medju Slovene od godine 1593 do 1597, „Starine” 1918, t. 36, ss. 9-22; P. Pierling, Novi izvori o L. Komuloviću, op.cit., ss. 220-231 (gdzie błędne datowanie tej instrukcji na 21 listopada 1593 r.).

${ }^{27}$ Zob. M. Jačov, I Balcani tra impero ottomano e potenze europee (sec. XVI e XVII). Il ruolo della diplomazia pontificia, Cosenza, Periferia, 1997, s. 70.

${ }^{28}$ Zob. O. Halecki, Od unii florenckiej do unii brzeskiej, t. 2, thum. A. Niklewicz, Lublin, Instytut Europy Sìrodkowo-Wschodniej, 1997, ss. 100-124.

${ }^{29}$ O pobycie Komulovicia w Wenecji zob. A. Trstenjak, Alessandro Komulovic S.I...., op.cit., s. 58; M. Jačov, I Balcani tra impero ottomano e potenze europee..., op.cit., s. 76. 
Polskiego polecono Komuloviciowi odbyć podobne konsultacje i narady również z władcą Mołdawii. Na terytorium polskim zalecano mu wielką ostrożność w kontaktach z dostojnikami z kręgu kanclerza wielkiego koronnego Jana Zamoyskiego. O sprawach mołdawskich i wołoskich rozmawiać miał z jezuitami oraz z arcybiskupem lwowskim Janem Dymitrem Solikowskim, w taki jednak sposób, aby nie odkryć przed nim zamiaru włączenia Kozaków do papieskiego projektu. W Rzymie obawiano się, że Polakom mogłoby się to z różnych powodów nie spodobać. Gdyby w trakcie pertraktacji pojawił się temat wodza chrześcijańskiej armii, to zdaniem kurialistów najbardziej odpowiednią i zdolną osobą do takiego przedsięwzięcia byłby wspomniany wyżej Jan Zamoyski, kanclerz Królestwa Polskiego i wielki hetman koronny. Jak napisano w instrukcji, ten wybitny dostojnik i mąż stanu, gdyby tylko zgodził się stanąć na czele chrześcijańskich wojsk, z pewnością mógłby liczyć na zaufanie i wsparcie Stolicy Apostolskiej. Posiadał on bowiem więcej doświadczenia, sławy i autorytetu niż ktokolwiek inny. Było jednak mało prawdopodobne, aby Zamoyski zdecydował się na poparcie tych planów z powodu jego znanej niechęci do Habsburgów i braku zaufania do Kozaków. Na koniec przypominano jeszcze raz papieskiemu dyplomacie o potrzebie dyskretnego prowadzenia rozmów, aby nie narażać niepotrzebnie papieskich projektów z powodu nierozważnie wypowiadanych słów ${ }^{30}$.

Powyższą instrukcję Komulović otrzymał na krótko przed opuszczeniem Rzymu, który nastąpił - jak się wydaje - nie wcześniej niż pod koniec listopada 1593 ro$\mathrm{ku}^{31}$. W tamtym momencie nie był jeszcze gotowy plan jego misji do Moskwy. Postanowiono zaczekać z jego uszczegółowieniem ze względu na potrzebę uzgodnienia niektórych kwestii z kancelarią cesarza Rudolfa II. Instrukcja moskiewska została sygnowana przez Klemensa VIII dopiero 27 stycznia 1594 roku i dostarczona Komuloviciowi kilka miesięcy później osobną pocztą dyplomatyczną ${ }^{32}$. Dokument ten nosił wyraźne ślady idei głoszonych przez chorwackiego duchownego. Podkreślono w nim znaczenie przynależności Moskwy do wspólnoty chrześcijańskich państw, których obowiązkiem było bronić „,wiary i Krzyża”, w tym także przed Turkami. Nie powinna być ona przy tym obojętna na pozostające pod tureckim panowaniem (,podobnego języka co moskiewski”) narody, które czekają na militarną

${ }^{30}$ Zob. A. Trstenjak, Alessandro Komulovic S.I..., op.cit., ss. 57-60; O. Halecki, The Renaissance Origin of Panslavism ..., op.cit., s. 14.

${ }^{31} \mathrm{Na} 8$ listopada datowane są listy kredencjalne do króla polskiego, wysokich dostojników Rzeczypospolitej oraz władców Mołdawii i Wołoszczyzny, zob. Vetera monumenta Poloniae et Lithuaniae gentiumque finitimarum historiam illustrantia, t. 3, red. A. Theiner, Romae, Typis Vaticanis, 1863, nr 164, s. 210.

${ }^{32}$ Komulović poinformował Sekretariat Stanu o otrzymaniu tej instrukcji i związanych z nią listów papieskich z Krakowa w dniu 27 października 1594 r., zob. P. Pierling, F. Rački, L. Komolovica izvještaj i listovi o poslanstvo..., op.cit., s. 108. 
i polityczną pomoc „swoich pobratymców”, aby zrzucić jarzmo niewoli. Nuncjusz papieski miał przekonywać swoich rozmówców, że do pokonania Turków potrzeba było nie tylko ich zaangażowania militarnego, ale również wsparcia dyplomatycznego. Ponieważ władca Moskwy utrzymywał dobre relacje z Persami, powinien zachęcać szacha do kontynuowania wojny z Osmanami. Korzystnie byłoby również wywierać silniejszą presję na Tatarów, najbliższych sojuszników sułtana. Stolicy Apostolskiej najbardziej zależało jednak na bezpośredniej pomocy wojskowej dla cesarza. Komuloviciowi polecono przedstawienie swoim rozmówcom wszystkich płynących z tego korzyści. Przede wszystkim wspólna walka z zachodnimi armiami, niemiecką, węgierską i włoską, podniosłaby zdolność bojową sił moskiewskich. Ich żołnierze mogliby zdobyć wiele nowych umiejętności przydatnych na ówczesnym polu bitwy. Ryzyko strat byłoby niewielkie, bo działania wojenne toczyłyby się poza moskiewskim terytorium, prawdopodobnie w Mołdawii i regionie czarnomorskim. Jak podkreślano $\mathrm{w}$ instrukcji, ziemie te charakteryzowały się łagodnym i przyjaznym klimatem. Ich zdobycie przyniosłoby wielkie korzyści Moskwie także z tego powodu, że otworzyłoby drogę wprost do Konstantynopola. Po jego odzyskaniu Stolica Apostolska nie miałaby innego wyjścia, jak przekazać go Moskwie jako zwycięskiemu sojusznikowi i najważniejszemu państwu prawosławnemu. Rzym zadbałby również o międzynarodowe uznanie tego faktu. Nie byłoby to trudne, bo większość państw chrześcijańskich uznawała autorytet Stolicy Apostolskiej w tym względzie. Także narody pozostające pod jarzmem tureckim - w większości wyznawcy prawosławia - na zawsze pozostałyby wdzięczne Moskwie za ich wyzwolenie. Komulović miał powiadomić Fiodora I, że papież - biskup Rzymu i prawdziwy namiestnik Chrystusa na ziemi - mógłby także nadać władcy Moskwy tytuł cesarza Wschodu. Nie mógł tego zaoferować nikt inny, w tym także obecny patriarcha Konstantynopola, który był całkowicie zależny od woli sułtana. $Z$ powyższymi kwestiami wiązała się ściśle sprawa unii Kościołów, oparta na zasadach wypracowanych na soborze florenckim. Jak się można domyślać, wszystkie powyższe obietnice mogły zostać przez Stolicę Apostolską dotrzymane tylko pod warunkiem uznania przez Moskwę prymatu papieża w świecie chrześcijańskim ${ }^{33}$.

Treść tej instrukcji wskazuje na to, że w kurii rzymskiej ciagle nie wyzbyto się utopijnych planów włączenia Moskwy w orbitę sojuszników papiestwa. Podejmując to wyzwanie, papiescy urzędnicy postanowili odsunać na bok przykre doświadczenia we wzajemnych relacjach z przeszłości ${ }^{34}$. Być może liczyli na to, że Komulović jako

${ }^{33}$ Zob. Biblioteca Apostolica Vaticana, Urb. lat. 866, f. 141r-152v. Pełne, krytyczne wydanie II instrukcji dla Aleksandra Komulovicia zob. Die Hauptinstruktionen Clemens' VIII..., op.cit., nr 33, ss. 225-232; Zob. także E. Fermendžin, Prilozi k poznavanju diplomatskoga ..., op.cit., ss. 22-28.

${ }^{34}$ Niepowodzeniem zakończyły się papieskie próby zawiązania unii kościelnej zarówno w XV jak i XVI w. Ostatnią z nich była słynna misja do Moskwy Antoniego Possevina SJ w latach 1581-1582, 
Słowianin pozyska więcej zrozumienia dla swoich propozycji niż jego poprzednicy. W Moskwie choć dominowała niechęć do łacińskiego Zachodu i współpracy z katolickimi sąsiadami, to wyjątkowo traktowano relacje $\mathrm{z}$ dworem cesarskim. $\mathrm{Z}$ tego też powodu na pierwszy plan został wysunięty aspekt potrzeby politycznego i wojskowego wsparcia dla cesarza Rudolfa II z jednoczesnym pominięciem jakichkolwiek wzmianek o Rzeczypospolitej. Nad Tybrem obawiano się niechętnego stanowiska kierowników polityki polskiej wobec tego projektu. Instrukcja nie wspominała również ani słowem o realizowaniu przez Rzym unii kościelnej z wyznawcami prawosławia w Rzeczypospolitej. Jak można przypuszczać, obawiano się, iż dla Moskwy mogłoby to stać się istotną przeszkodą w zawarciu antytureckiego porozumienia ${ }^{35}$. Instrukcja wystawiona dla Komulovicia była promoskiewska. Nic więc dziwnego, że polecono mu zachowywać jej treść w głębokiej tajemnicy przed polskimi i litewskimi rozmówcami. Nie ulega wątpliwości, że wyjawienie treści tego dokumentu wiązałoby się z ryzykiem utraty zaufania do Stolicy Apostolskiej jednego z najwierniejszych sojuszników w Europie.

Początek dyplomatycznej misji Aleksandra Komulovicia w Europie ŚrodkowoWschodniej nastąpił w Siedmiogrodzie, dokąd przybył w połowie stycznia 1594 roku. W Alba Julia, stolicy tego księstwa, skontaktował się ze spowiednikiem księcia Zygmunta Batorego, jezuitą Alfonsem Carrillo, i z jego pomocą rozpoczął przekonywanie tego władcy do przyjęcia papieskich propozycji. Namowy te trwały kilka tygodni i zakończyły się sukcesem ${ }^{36}$. Komulović uskrzydlony powodzeniem udał się pod koniec marca do Mołdawii, gdzie w Jassach przeprowadził podobne negocjacje z wojewodą Aaronem. Głównym ich tematem była kwestia powstrzymania Tatarów chcących poprzez Mołdawię przedostać się na Węgry ${ }^{37}$. W ostatnich dniach marca wysłannik papieski przebywał już w granicach Rzeczypospolitej. Swoją bazą wypadową uczynił Kamieniec Podolski ${ }^{38}$. W następnych dniach prowadził rozmowy

zob. S. Polčin, Une tentative d'Union au XVIe siècle. La Mission réligieuse du Père Antoine Possevin SJ en Moscovie (1581-82), Roma, Pont. Institutum Orientalium Studiorum, 1957, ss. 1-141; J.J. Santich, Missio Moscovitica..., op.cit., ss. 85-105.

${ }^{35}$ Zob. O. Halecki, The Renaissance Origin of Panslavism, op.cit., s. 18; A. Kadić, Krizanic's Formative Years, [w:] From Croatian Renaissance to Yugoslav Socialism, red. C.H. Van Schooneveld, Hague - Paris, De Gruyter Mouton, 1969, s. 49.

${ }^{36}$ Zob. P. Pierling, La Russie et le Saint-Siège..., op.cit, ss. 337-340; A. Trstenjak, Alessandro Komulovic S.I..., op.cit., s. 61. Na temat działaności Alfonsa Carillo SJ w Siedmiogrodzie w momencie wybuchu długiej wojny z Turcją, zob. L. Szilas, Alfonso Carrillo jezsuita Erdélyben (1591-1599), Budapest, METEM, 2001, ss. 47-58.

${ }^{37}$ Zob. A. Trstenjak, Alessandro Komulovic S.I..., op.cit., s. 62.

${ }^{38}$ Dnia 31 marca wysłał do sekretarza stanu Stolicy Apostolskiej, kardynała Cinzio Passeri Aldobrandiniego, list, w którym informował go o swoim przyjeździe dwa dni wcześniej do Kamieńca Podolskiego, zob. P. Pierling, F. Rački, L. Komolovica izvještaj i listovi o poslanstvo..., op.cit., s. 95; A. Trstenjak, Alessandro Komulovic S.I...., op.cit., s. 62. 
z miejscowym dostojnikami, z których najpotężniejszym był wojewoda kijowski Konstanty Wasyl Ostrogski ${ }^{39}$. Ku zadowoleniu nuncjusza, potężny magnat zapewnił go, że w razie ogłoszenia wojny osobiście poprowadzi swoje oddziały zarówno przeciwko Turkom, jak i Tatarom ${ }^{40}$. O wiele trudniejsze pertraktacje czekały go jednak z hetmanem koronnym i wielkim kanclerzem Janem Zamoyskim. Doszło do nich w dniach 20-21 kwietnia, w posiadłości kanclerza położonej niedaleko Lwowa. Zamoyski nie dał Komuloviciowi zbyt wielu nadziei na szybkie zaangażowanie się Rzeczypospolitej w papieskie projekty, przede wszystkim ze względu na nieobecność króla w kraju. Wielki kanclerz uważał, że dopiero po jego powrocie, który spodziewany był jesienią, będzie można przedstawić w sprawie Ligi jakieś większe konkrety. Według jego oceny o zaangażowaniu Rzeczypospolitej w wojnę z Turcją zdecydować mógł dopiero sejm obradujący pod osobistym przewodnictwem króla. Komulović przyjął te thumaczenia i poprzestał na prośbie o blokowanie Tatarom do tego czasu przejścia przez terytorium Rzeczypospolitej na Wegry. Choć kanclerz obiecał zadośćuczynić jego prośbom odnoszącym się do bieżącej sytuacji, to dostrzec można było u niego niechęć do składania jakichkolwiek deklaracji na przyszłość. Dlatego też Komulović prosił Rzym, aby jak najszybciej wysłano do Polski obdarzonego najwyższymi kompetencjami papieskimi legata de latere. Jego zdaniem, tylko osoba z najbliższego otoczenia papieża będzie w stanie pozytywnie wpłynąć na takich możnowładców jak Zamoyski, od których zależała zgoda Rzeczypospolitej na wojnę z Turcją ${ }^{41}$.

Po pertraktacjach z Janem Zamoyskim Komulović wrócił do Kamieńca Podolskiego, zamierzając nawiązać kontakt z Kozakami. Miał bowiem przy sobie skierowane do nich papieskie listy $\mathrm{z}$ wezwaniem do jak najszybszego przystapienia do wojny z Turkami i blokowania Tatarom przejścia na węgierski teatr wojenny ${ }^{42}$. Nuncjusz rozważał podróż na Sicz Zaporoską, ale zrezygnował z niej z powodów bezpieczeństwa. Do jego rozmów z przedstawicielami Kozaków doszło prawdopodobnie w okolicach Kamieńca Podolskiego. Na temat tych pertraktacji niewiele wiadomo. Znany jest natomiast projekt realizowany latem 1594 roku w porozumieniu z politycznym rywalem Zamoyskiego, starostą śniatyńskim Mikołajem Jazłowieckim. Za

${ }^{39} \mathrm{O}$ przebiegu tych rozmów dowiadujemy się z listu Komulovicia, wysłanego ze Lwowa w dniu 27 kwietnia 1594 r., adresowanego do papieskiego Sekretariatu Stanu, zob. P. Pierling, F. Rački, L. Komolovica izvještaj i listovi o poslanstvo..., op.cit., ss. 97-100.

${ }^{40}$ Ibidem, s. 97.

${ }^{41}$ Ibidem, ss. 98-100; A. Trstenjak, Alessandro Komulovic S.I..., op.cit., s. 63.

${ }^{42}$ Vetera monumenta Poloniae et Lithuaniae..., op.cit., nr 164, s. 211; Documenta Pontificum Romanorum historiam Ucrainae illustrantia (1075-1953), t. 1, red. A.G. Welykyj, Romae, PP. Basiliani, 1953, nr 129, ss. 233-234 i nr 130, ss. 234-235; C. Pausz, Das Krim-Khanat und der Aufstieg des Zaporoger Kosakentums. Erich Lassotas Mission im diplomatischen Kontext, „Österreichische Zeitschrift für Geschichtswissenschaften" 2017, t. 28, nr 1, s. 28. 
namową Komulovicia podjął się on, za sumę 10 tysięcy florenów, sformowania armii, która miała pomaszerować przeciwko Tatarom na Krym. Wykorzystując te fundusze, przystąpił do formowania wojska liczącego około dwóch tysięcy ludzi. Uzyskał on również obietnicę wsparcia ze strony dwukrotnie liczniejszych oddziałów kozackich. Cały plan zakończył się jednak spektakularnym niepowodzeniem. Najemnicy Jazłowieckiego, wkrótce po odebraniu żołdu, porzucili go kierując się nie na Krym, ale na Wołoszczyznę. Dla Aleksandra Komulovicia był to potężny cios. Nieporadnie musiał wyjaśniać później w sekretariacie stanu fakt zmarnowania funduszy papieskich. Wydaje się też, że powyższa sprawa nauczyła go zrozumienia dla ostrożnego podejścia kierowników polskiej polityki do niepewnego żywiołu, jakim byli już wówczas Kozacy ${ }^{43}$.

Komulović zrezygnował wówczas z poszukiwania alternatywnych rozwiązań, przeniósł się do Krakowa i przystapił do pozyskiwania dla papieskich projektów poważnych sojuszników. Pomagał mu w tym, znający dobrze meandry polskiej polityki, wieloletni nuncjusz w Rzeczypospolitej, Germanico Malaspina. Komulović dowiedział się od niego, że choć Zygmunt III popierał plany wojny z Turcja, to większość możnowładców podzielała stanowisko Jana Zamoyskiego. Podobnie jak kanclerz wielki koronny, obawiali się w razie powodzenia Ligi Świętej nadmiernego wzmocnienia pozycji Habsburgów. Komulović nie widząc szans na szybkie przełamanie w tym względzie oporu, utwierdzał się coraz bardziej w przekonaniu o potrzebie wyjazdu do Moskwy. Konsultował się w tej sprawie między innymi z sekretarzem stanu, kardynałem Cinzio Paserrim Aldobrandinim. W liście z Krakowa datowanym 27 października 1594 roku dziękował za przesłaną mu instrukcję na moskiewską misję z dnia 29 stycznia oraz podarunki dla wielkiego księcia Fiodora ${ }^{44}$. W kolejnym liście, wysłanym trzy tygodnie później, Komulović wyraził wątpliwość wobec możliwości współpracy wojskowej Rzeczypospolitej z Moskwą. Proponował zatem, aby rozważyć Ligę Świętą w oparciu wyłącznie o sojusz Moskwy z cesarstwem, Hiszpanią i niektórymi państwami włoskimi ${ }^{45}$.

Tymczasem wbrew obawom Komulovicia sejm, który zebrał się w Krakowie 6 lutego 1595 roku, nie odrzucił możliwości przyłączenia się Rzeczypospolitej do Ligi Świętej. Posłowie postawili jednak własne warunki. Przede wszystkim żądali, aby arcyksiążę Maksymilian Habsburg zrzekł się roszczeń do polskiej korony, do czego zobowiązał się w zapośredniczonych przez Stolicę Apostolską traktatach

${ }^{43}$ Zob. R. Żelewski, Jazłowiecki Mikołaj h. Abdank, [w:] Polski słownik biograficzny, t. 11, Wrocław 1964-1965, s. 125; B. Kocowski, Wyprawa Tatarów na Wegry przez Polskę w 1594 r., Lublin, Towarzystwo Naukowe KUL, 1948, ss. 64-66; P. Pierling, F. Rački, L. Komolovica izvještaj i listovi o poslanstvo..., op.cit., ss. 100-105; A. Trstenjak, Alessandro Komulovic S.I..., op.cit., s. 63-64; P. Pierling, La Russie et le Saint-Siège..., op.cit, ss. 347-349.

${ }^{44}$ Zob. P. Pierling, F. Rački, L. Komolovica izvještaj i listovi o poslanstvo..., op.cit., s. 108.

${ }^{45}$ Ibidem, ss. 120-124; A. Trstenjak, Alessandro Komulovic S.I..., op.cit., s. 63. 
bytomsko-będzińskich. Rzym miał ponadto zaprzestać kontaktowania się z Kozakami, o których pomoc zabiegał - jak z sarkazmem podkreślano - bez zasięgania opinii i rady Polaków. W końcu polscy dostojnicy nie chcieli zaakceptować faktu, że zgodnie z wolą papieża Siedmiogród, Mołdawia, Wołoszczyzna i Bułgaria w razie wygranej wojny miały przypaść Habsburgom, a Konstantynopol Moskwie. Z całą mocą podkreślano, że państwo polsko-litewskie powinno mieć swój udział w przyszłym podziale terytoriów odebranych Turkom ${ }^{46}$. Powyższe postulaty ukazywały słabe punkty dotychczasowej polityki papieskiej i stawiały Klemensa VIII w niezwykle trudnym położeniu - głównie z powodu sztywnej i nieustępliwej postawy cesarza.

W tej sytuacji Stolica Apostolska zdecydowała się wysłać Aleksandra Komulovicia do Moskwy, aby wybadał także i jej stanowisko. Nuncjuszowi nakazano realizację powierzonego mu wcześniej planu działania. O pozwolenia na przejazd i paszporty na drogę Komulović zwrócił się do kanclerza wielkiego koronnego Jana Zamoyskiego i biskupa krakowskiego Jerzego Radziwiłła. Po ich uzyskaniu papieski dyplomata opuścił Wilno i wyruszył w stronę granicy z Wielkim Księstwem Moskiewskim drogą prowadzącą przez Smoleńsk ${ }^{47}$. Nuncjusz miał przy sobie list Klemensa VIII, w którym polecał on swojego posła - ,iliryjskiego księdza Aleksandra Comulusa", jako osobę godną zaufania i cieszącą się powszechnie jak najlepszą opinią. Papież pisał, iż jest to człowiek mądry, święty i pobożny oraz miły Bogu. Był też przekonany, że znajomość języków słowiańskich ułatwi mu realizację czekających go zadań. $\mathrm{Z}$ tego pisma dowiadujemy się również, że jako znak przyjaźni i dobrej woli oraz symbol wspólnoty w wierze, „,której należało bronić przed muzułmańskim niebezpieczeństwem", nuncjusz miał przekazać w darze Fiodorowi I złoty krucyfiks ozdobiony wspaniałymi szmaragdami ${ }^{48}$.

Po przybyciu na moskiewski dwór Komulović zdał sobie sprawę, że prawdziwym panem kraju wcale nie był Fiodor I, ale bojar tatarskiego pochodzenia Borys Godunow. To on prowadził w imieniu władcy główne pertraktacje. W ich trakcie

${ }^{46}$ Zob. Rajnolda Hejdensztejna, sekretarza królewskiego, Dzieje Polski od śmierci Zygmunta Augusta do roku 1594, thum. M. Gliszczyński, t. 2, Petersburg, B.M. Wolff, 1857, ss. 328-332; A. Barwicka, Rzeczpospolita w planach dyplomacji papieskiej i habsburskiej w okresie wojny austriacko-tureckiej 1593-1606, [w:] Polska wobec wielkich konfliktów w Europie nowożytnej, red. R. Skowron, Kraków, Societas Vistulana, 2009, ss. 301-302; J. Milewski, Między patronatem a wspótpracq-relacje Jana Zamoyskiego i hospodara mołdawskiego Jeremiego Mohyly (1595-1605), „Wieki Stare i Nowe”, tom specjalny, 2012, s. 16.

${ }^{47}$ Zob. A. Trstenjak, Alessandro Komulovic S.I...., op.cit., ss. 65-67. Komulović wiózł też ze sobą list polecający wystawiony przez króla Zygmunta III Wazę, zob. P. Pierling, Novi izvori o L. Komuloviću, op.cit., s. 236.

${ }^{48}$ Zob. List Klemensa VIII do Fiodora I z 22 stycznia 1594 r. Vetera monumenta Slavorum Meridionalium historiam illustrantia, t. 2, red. A. Theiner, Zagrabiae, Academia Scientiarum et Artium Salvorum Meridionalium, nr 93, ss. 86-87; Historica Russiae Monumenta ex antiquis exterarum gentium archivis et bibliothecis deprompta, t. 2, red. A.J. Turgenev, Petropoli, Typis Eduardi Pratzi, 1842, nr 26, ss. 45-47. 
Godunow poinformował papieskiego wysłannika, że Moskwa nie zamierza wojować z Turkami, ani z ich sojusznikami, Tatarami. Jeśli jednak władcom zachodnim tak bardzo na tym zależy, to niech przybędą sami albo wyślą swoich ambasadorów do Moskwy w celu negocjowania warunków takiego paktu. Papieski wysłannik zorientował się, że warunek ten zmierzał do storpedowania prowadzonych przez niego pertraktacji. Rzeczywiście utknęły one w martwym punkcie i ostatecznie zakończyły się niepowodzeniem ${ }^{49}$.

Dnia 22 maja 1595 roku Komulović opuścił Moskwę i udał się z powrotem do Wilna $^{50}$. Wiózł ze sobą list od wielkiego księcia Fiodora do papieża. Pisemny raport z tej misji trafił też do sekretarza stanu, kardynała Cinzia Passeriego Aldobrandiniego. Sekretarz stanu poinformował o tym przebywającego w Warszawie nuncjusza Malaspinę. W raporcie nie ukrywał swojego rozczarowania wynikami moskiewskich narad. Jedynie papież Klemens VIII ciągle wierzył w zmianę stanowiska Moskwy, zwłaszcza po włączeniu się do rozmów dyplomatycznych przedstawicieli cesarza Rudolfa II. Komuloviciowi polecono więc nie opuszczać Wilna i czekać tam na kolejne wskazówki ${ }^{51}$.

Wiosną 1596 roku Klemens VIII, odpowiadając na monity Aleksandra Komulovicia, zdecydował się w końcu wysłać do Królestwa Polskiego legata a latere. Do tego zadania wybrano doświadczonego dyplomatę, kardynała Enrica Caetaniego. Jego głównym zadaniem miało być przyspieszenie procesu budowy w Europie Środkowej antytureckiej Ligi Świętej. Na okoliczność nowej misji Komulovicia na Wschód wiózł ze sobą między innymi nowe listy papieskie oraz bogate podarki dla moskiewskiego władcy ${ }^{52}$. W tym samym czasie nuncjusz Germanico Malaspina zaangażowany był w negocjacje dotyczące unii Kościoła prawosławnego z Rzymem. Kilka miesięcy wcześniej bullą Magnus Dominus z 23 grudnia 1595 roku Klemens VIII zaakceptował warunki postawione przez Rusinów. Należały do nich między innymi utrzymanie wschodniej liturgii i kalendarza juliańskiego oraz zwolnienie niższego duchowieństwa z obowiązku celibatu ${ }^{53}$. Po przyjeździe legata Caetaniego

${ }^{49}$ Zob. P. Pierling, Papes et Tsars (1547-1597). D'Après des Documents Nouveaux, Paris, RetauxBray, 1890, s. 467; A. Trstenjak, Alessandro Komulovic S.I...., op.cit., s. 67.

${ }^{50}$ Zob. P. Pierling, Papes et Tsars, op.cit., s. 469.

${ }^{51}$ A. Trstenjak, Alessandro Komulovic S.I..., op.cit., ss. 67-68.

${ }^{52}$ Zob. Ibidem, ss. 71-72. Na temat misji legackiej kardynała Enrico Caetaniego do Królestwa Polskiego zob. J. Smołucha, Legacja kardynała Enrica Caetaniego do Rzeczypospolitej w latach 15961597 w świetle instrukcji generalnych z czasów pontyfikatu papieża Klemensa VIII, [w:] Sztuka roztropności. Dyplomacja Stolicy Apostolskiej wobec Rzeczypospolitej, Europy i świata w epoce nowożytnej i XX wieku. Zbiór studiów, red. K. Ożóg, R. Skowron, Kraków, Polska Akademia Umiejętności, 2020, ss. 91-105.

${ }^{53}$ Na pamiątkę tego wydarzenia papież nakazał wybić medal „Ruthenis receptis”, zob. J. Krasiński, Unia brzeska: kontekst i treść aktu uniijnego, unici, „Studia Theologica Varsaviensia” 1997, t. 35, nr 1, s. 149. Więcej na ten temat zob. O. Halecki, Od unii florenckiej do unii brzeskiej, t. 2, op.cit., ss. $158-198$. 
do Polski w czerwcu 1596 roku nuncjusz Malaspina na bieżąco składał mu raporty z toczących się negocjacji z Rusinami. Ostatecznie w październiku 1596 roku na synodzie w Brześciu unia została przyjęta przez większość władyków z Rzeczypospolitej Obojga Narodów ${ }^{54}$.

Ten wiekopomny akt stał się nowym elementem w relacjach między Kościołem katolickim a Kościołami prawosławnymi, stając się wyzwaniem dla całego prawosławia. Rzym z początku nie rozumiał skutków nowej rzeczywistości polityczno-religijnej w Europie Wschodniej. Tymczasem Moskwa, która od czasu upadku Konstantynopola w 1453 roku uważała się w za obrońcę całego prawosławia, została głęboko urażona zawiązaniem unii brzeskiej, o czym przekonać się miał wkrótce sam Komulović. Wysłannik papieski, oczekując w Wilnie na dalsze decyzje Stolicy Apostolskiej w sprawie swojej misji mokiewskiej, nie był świadomy tych zmian. Gdy trwające ponad sześć miesięcy zabiegi kardynała Caetaniego nie przyniosły osłabienia niechętnego stanowiska Polaków do wojny z Turcją, Rzym zdecydował się wysłać Komulovicia ponownie na dwór moskiewski. Nuncjusz Malaspina jeszcze latem 1596 roku przesłał mu na tę okoliczność kilka porad. Przede wszystkim Komulović powinien uzyskać jasną deklarację w sprawie udziału Moskwy w budowanej przez papieża lidze antytureckiej. Gdyby usłyszał odmowę, miał przede wszystkim nakłaniać Fiodora I do powstrzymania Tatarów przed najazdami na Europę Środkową. Nuncjusz miał też prosić o gwarancję bezpieczeństwa dla Zygmunta III Wazy, który zadeklarował już swój udział w wojnie z Turcją. Ostatnią kwestią było przyłączenie się do unii kościelnej, którą Stolica Apostolska zawarła z wyznawcami prawosławia w Rzeczypospolitej ${ }^{55}$.

Do potrzeby ponownego wyjazdu Komulovicia do Moskwy, pomimo dostrzegania ryzyka tego przedsięwzięcia, przekonywał się też coraz bardziej legat Enrico Caetani. Pod koniec stycznia 1597 roku pisał z Krakowa do nuncjusza na dworze cesarskim w Pradze, że z powodu zakończenia negocjacji w sprawie antytureckiej Ligi w Rzeczypospolitej powinno się podjać jeszcze jedną próbę uzyskania pomocy od Moskwy. Kardynał wspomniał Komulovicia, który od długiego czasu czekał w Wilnie na pozwolenie udania się na Wschód ${ }^{56}$. Według Caetaniego powinien on dołączyć do poselstwa cesarza Rudolfa II, które od dawna przygotowywało się do wyjazdu do Moskwy. Kardynał miał nadzieję na silniejsze umocowanie dyploma-

${ }^{54}$ Zob. O. Halecki, Od unii florenckiej do unii brzeskiej, t. 2, op.cit., ss. 232-265.

${ }^{55}$ Zob. P. Pierling, Papes et Tsars, op.cit., s. 471. Jeszcze w listopadzie 1596 r. w Rzymie utrzymywano, że już wkrótce Moskwa uzna papieża „prawdziwym wikariuszem Chrystusa, głową i uniwersalnym pasterzem całego chrześcijaństwa”, zob. Biblioteca Apostolica Vaticana, Urb. lat. 1064, f. 776; O. Halecki, Od unii florenckiej do unii brzeskiej, t. 2, op.cit., s. 294.

${ }^{56}$ Zob. Archivio Apostolico Vaticano (dalej AAV), Segr. Stato, Nunziature Diverse 273, f. 217r-217v; P. Pierling, Novi izvori o L. Komuloviću, op.cit., s. 242. 
tyczne Komulovicia, który był dyplomatą niższego szczebla ${ }^{57}$. To prawdopodobnie nuncjusz w Rzeczypospolitej, Germanico Malaspina, uświadomił Caetaniemu, że wizyty dyplomatyczne w Moskwie posiadają odmienną od zachodniej charakterystykę. Jej główną cechą było przywiązywanie dużego znaczenia do pompatycznego ceremoniału dworskiego. W jednym ze swoich raportów do Rzymu Malaspina pisał, że tam:

„[...] dove è maggiormente riconosciuto il principato temporale, che il primato di Pietro devono farsi le missioni rari, ma con pompa et solemnità (gdzie uznaje się księstwo doczesne, a nie prymat Piotra, należy wykonywać rzadkie misje, ale z pompą i powagą, thum. autora)"s8.

Nie zgodził się z jego stanowiskiem sekretarz stanu, kardynał Cinzio Aldobrandini. Nakazał, aby Komulović w drogę do Moskwy nie zabierał ze sobą więcej niż dwóch służących. Jak zauważył, oszczędzone wydatki będzie można dzięki temu wykorzystać przy innej okazji ${ }^{59}$. Komuloviciowi nie pozostało nic innego niż zastosować się do tego zalecenia.

Wyjeżdżając do Moskwy, Aleksander Komulović wiózł ze sobą listy od papieża Klemensa VIII. Jeden z nich przeznaczony był dla Fiodora I, a drugi dla Borysa Godunowa. Warto na te listy zwrócić uwagę, ponieważ po raz pierwszy w dziejach papież tytułował w nich władcę Moskwy carem ${ }^{60}$. Można domniemywać, że papież zdecydował się na użycie tej tytulatury, chcąc uprzedzić w tym względzie cesarza Rudolfa $\mathrm{II}^{61}$.

W drugą misję do Moskwy Aleksander Komulović wyruszył pod koniec marca 1597 roku. Zgodnie zzaleceniem sekretarza stanu, kardynała Cinzio Aldobrandiniego, wziął ze sobą tylko jednego pomocnika, którym był kanonik katedry wileńskiej

${ }^{57}$ Zob. AAV, Segr. Stato, Nunziature Diverse 273, f. 77r-77v; T. Trstenjak, Aleksandar Komulović kao mogući uzor Jurju Križaniću...., op.cit., s. 296; P. Pierling, Novi izvori o L. Komuloviću, op.cit., ss. 239-240. O kontaktach dyplomacji cesarskiej z Moskwą w latach 90. XVI w. zob. V. Panov, Tři moskevské mise Mikuláše Varkoče 1589-1594 ve světle diplomatického rituálu Ruska, „Opera historica. Časopis pro dějiny raného novověku", 2019, nr 20/1, ss. 7-19.

${ }^{58}$ P. Pierling, Novi izvori o L. Komuloviću, op.cit., s. 238; A. Trstenjak, Alessandro Komulovic S.I...., op.cit., s. 74.

${ }^{59}$ Zob. A. Trstenjak, Alessandro Komulovic S.I..., op.cit., s. 74.

${ }^{60}$ Zob. Historica Russiae Monumenta..., t. 2, op.cit., nr 27, ss. 48-49; nr 28, s. 49.

${ }^{61}$ Latem 1597 r. krążyła na Litwie pogłoska, że Rudolf II przekazał już Fiodorowi I koronę królewska, zob. P. Pierling, Papes et Tsars, op.cit., s. 471. Przeciwko planom przekazania Fiodorowi I korony królewskiej protestował też u nuncjusza Malaspiny król Zygmunt III, zob. O. Halecki, Od unii florenckiej do unii brzeskiej, t. 2, op.cit., s. 294. Kwestia uznania tytułu cara Fiodora I pojawiła się w korespondencji, jaką prowadził nuncjusz Malaspina z Sekretariatem Stanu. Uważał on, że należy nazywać Fiodora I carem, bo tak zaczął go tytułować od pewnego czasu sam cesarz Rudolf II, zob. A. Trstenjak, Alessandro Komulovic S.I...., op.cit., s. 73. 
Bulpato. Po przekroczeniu granicy Wielkiego Księstwa Moskiewskiego obydwaj zostali niespodziewanie aresztowani i pod eskortą zabrani do Smoleńska. Tam zostali wtrąceni do więzienia pod zarzutem szpiegostwa. Po kilku tygodniach złego traktowania papieski wysłannik i jego towarzysz zostali przewiezieni pod strażą wojskową na osobiste polecenie Fiodora I do Moskwy ${ }^{62}$. Także w stolicy trzymano ich pod eskorta, utrudniając kontakt z delegacją cesarską, która przebywała wówczas w Moskwie. Dopiero po długich staraniach delegacja papieska została przyjęta przez Fiodora I, któremu towarzyszył Borys Godunow. Jak można przypuszczać, w trakcie audiencji Komulović trzymał się punktów zapisanych w instrukcji papieskiej i wspomnianych wyżej dodatkowych wskazówek przekazanych mu przez nuncjusza Malaspinę ${ }^{63}$.

O efektach prowadzonych w Moskwie rozmów można dowiedzieć się więcej z treści dwóch listów do papieża Klemensa VIII, przekazanych Komuloviciowi przez Fiodora I na krótko przed jego wyjazdem z Moskwy. W pierwszym car nie szczędził obietnic i dobrych rad. Moskiewski władca podkreślał swoje przywiązanie do chrześcijańskiej wiary i woli zaangażowania się na rzecz jej obrony przed wszystkimi wrogami. Fiodor I donosił papieżowi o uruchomieniu działań dyplomatycznych w kwestii przeciwstawienia się ekspansji tureckiej. Należały do nich kontakty z szachem perskim, którego zachęcał do kontynuowania wojny z Turkami. Moskiewski władca obiecał też powstrzymywać Tatarów przed udzielaniem wsparcia sułtanowi. Choć Fiodor I deklarował chęć udzielenia pomocy cesarzowi Rudolfowi II, to w sprawie przystąpienia do Ligi Świętej był wstrzemię́liwy. W tej kwestii moskiewski władca oczekiwał przybycia na swój dwór ambasadorów zachodnich, aby uzgodnić szczegóły takiego sojuszu. Umowa taka miałaby objąć również porozumienie z perskim szachem Abbasem $\mathrm{I}^{64}$. Z kolei w drugim swoim liście Fiodor I informował papieża, że nastąpił w ostatnim czasie wzrost napięcia między Moskwą a Szwecją, która nie przestrzega postanowień zawartego kilka lat wcześniej traktatu pokojowego. Ponieważ nie zostały Moskwie zwrócone obiecane miasta i fortece ostrzegał, iż nieunikniona będzie nowa wojna. W obydwu pismach nie było natomiast ani jednej wzmianki na temat ewentualnej unii Kościołów ${ }^{65}$.

Dwie moskiewskie misje papieskiego wysłannika Aleksandra Komulovicia zakończyły się fiaskiem. Dyplomacja Stolicy Apostolskiej, przy całej swojej wiedzy i rozpoznaniu merytorycznemu, po raz kolejny okazała swoją naiwność i życzeniowe

${ }^{62}$ Zob. P. Pierling, Papes et Tsars, op.cit., s. 472; Idem, La Russie et le Saint-Siège..., op.cit, ss. 365-366; T. Trstenjak, Aleksandar Komulović kao mogući uzor Jurju Križaniću...., op.cit., ss. 297-298; A. Trstenjak, Alessandro Komulovic S.I...., op.cit., ss. 74-75.

${ }^{63}$ Zob. A. Trstenjak, Alessandro Komulovic S.I...., op.cit., s. 75.

${ }^{64}$ Zob. P. Pierling, Novi izvori o L. Komuloviću, op.cit., ss. 243-248.

${ }^{65}$ Zob. Ibidem, ss. 248-250; P. Pierling, Papes et Tsars, op.cit., s. 473; Idem, La Russie et le SaintSiège..., op.cit, s. 367; A. Trstenjak, Alessandro Komulovic S.I..., op.cit., s. 75. 
myślenie. W tamtym czasie odpowiadał za to w dużym stopniu sam Komulović, który swoim przesadnym optymizmem inicjował działania kilku kolejnych papieży. Także Klemens VIII, dla którego sprawa obrony chrześcijańskiej Europy przed Turkami stała na pierwszym miejscu, uwierzył w jego zapewnienia o możliwości zjednoczenia wokół tej idei sił wszystkich narodów słowiańskich. Udział Moskwy w lidze antyotomańskiej był w tamtym czasie pobożnym życzeniem. Chorwacki duchowny w służbie papieskiej nie wziął pod uwagę tego, że Moskwa podążała od zawsze drogą, która wykluczała jakiekolwiek sojusze i porozumienie ze światem zachodnim. Okazało się to prawdą także i tym razem.

\section{Literatura}

Źródła

Archivio Apostolico Vaticano, Segr. Stato, Nunziature Diverse 273.

Biblioteca Apostolica Vaticana, Urb. lat. 866.

Biblioteca Apostolica Vaticana, Urb. lat. 1057.

Biblioteca Apostolica Vaticana, Urb. lat. 1064.

Biblioteca Apostolica Vaticana, Vat. Lat. 5440.

Biblioteca Apostolica Vaticana, Vat. lat. 13460.

Acta Bosnae potissimum ecclesiastica cum insertis editorum documentorum regestis ab anno 925 usque ad annum 1752, red. E. Fermendžin, Zagreb, Taberna libraria, $1892,620 \mathrm{ss}$.

Documenta Pontificum Romanorum historiam Ucrainae illustrantia (1075-1953), t. 1, red. A.G. Welykyj, Romae, PP. Basiliani, 1953, 686 ss.

Fermendžin E., Prilozi k poznavanju diplomatskoga poslanstva Aleksandra Komulovića medju Slovene od godine 1593 do 1597, „Starine” 1918, t. 36, ss. 7-30.

Die Hauptinstruktionen Clemens' VIII. für die Nuntien und Legaten an den europäischen Fürstenhöfen (1592-1605), wyd. K. Jaitner, t. 1, Tübingen, M. Niemeyer, 1984, 1329 ss.

Die Hauptinstruktionen Clemens 'VIII. für die Nuntien und Legaten an den europäischen Fürstenhöfen (1592-1605), wyd. K. Jaitner, t. 2, Tübingen, M. Niemeyer, 1984, 1040 ss.

Historica Russiae Monumenta ex antiquis exterarum gentium archivis et bibliothecis deprompta, t. 2, red. A.J. Turgenev, Petropoli, Typis Eduardi Pratzi, 1842, 449 ss.

Mosconi N., La nunziatura di Praga di Cesare Speciano (1592-1598): nelle carte inedite vaticane e ambrosiane, t. 3, Brescia, Morcelliana, 1966, 282 ss. 
Pierling P., Novi izvori o L. Komuloviću, „Starine” 1884, t. 16, ss. 209-251.

Pierling P., F. Rački, L. Komolovica izvještaj i listovi o poslanstvo njegovu u Torsku, Erdelj, Moldavsku i Poljsku, „Starine” 1882, t. 14, ss. 83-124.

Rajnolda Hejdensztejna, sekretarza królewskiego, Dzieje Polski od śmierci Zygmunta Augusta do roku 1594, thum. M. Gliszczyński, t. 2, Petersburg, B.M. Wolff, 1857,484 ss.

Vetera monumenta Poloniae et Lithuaniae gentiumque finitimarum historiam illustrantia, t. 3, red. A. Theiner, Romae, Typis Vaticanis, 1863, 771 ss.

Vetera monumenta Slavorum Meridionalium historiam illustrantia, t. 2, red. A. Theiner, Zagrabiae, Academia Scientiarum et Artium Slavorum Meridionalium, 1875,346 ss.

Opracowania

Bartl P., „,Marciare verso Costantinopoli” - Zur Türkenpolitik Klemens' VIII, „Saeculum" 1969 , t. 20, ss. 44-56.

Barwicka A., Rzeczpospolita w planach dyplomacji papieskiej i habsburskiej w okresie wojny austriacko-tureckiej 1593-1606, [w:] Polska wobec wielkich konfliktów w Europie nowożytnej, red. R. Skowron, Kraków, Societas Vistulana, 2009, ss. 297-307.

Coltrinari F., Loreto as an Illyrian Shrine. The Artistic Heritage of the Illyrian Confraternities and College in Loreto and Recanati, „Confraternitas” 2016, t. 27, nr 1-2, ss. 46-61.

Fine J.V.A., When Ethnicity Did Not Matter in the Balkans, Ann Arbor, University of Michigan Press, 2006, 652 ss.

Gregorowicz D., Tiara w grze o koronę. Stolica Apostolska wobec wolnych elekcji w Rzeczypospolitej Obojga narodów w drugiej połowie XVI wieku, Kraków, Polska Akademia Umiejętności, 2019, 496 ss.

Gudelj J., The Hospital and Church of the Schiavoni/Illyrian Confraternity in Early Modern Rome, „Confraternitas” 2016, t. 27, nr 1-2, ss. 5-29.

Gudelj J., San Girolamo dei Croati a Roma. Gli Schiavoni e il cantiere sistino, [w:] Identità e rappresentazione. Le chiese nazionali a Roma, 1450-1650, red. A. Koller, S. Kubersky-Piredda, Roma, Campisano Editore, 2015, ss. 297-325.

Halecki O., Od unii florenckiej do unii brzeskiej, t. 2, tłum. A. Niklewicz, Lublin, Instytut Europy Środkowo-Wschodniej, 1997, 344 ss.

Halecki O., The Renaissance Origin of Panslavism, „,The Polish Review” 1958, t. 3, nr 1/2, ss. 7-19.

Jačov M., I Balcani tra impero ottomano e potenze europee (sec. XVI e XVII). Il ruolo della diplomazia pontificia, Cosenza, Periferia, 1997, 280 ss. 
Kadić A., Krizanic's Formative Years, [w:] From Croatian Renaissance to Yugoslav Socialism, red. C.H. Van Schooneveld, Hague, De Gruyter Mouton, 1969, ss. 41-73.

Kocowski B., Wyprawa Tatarów na Węry przez Polskę w 1594 r., Lublin, Towarzystwo Naukowe KUL, 1948, 70 ss.

Krasiński J., Unia brzeska: kontekst i treść aktu uniijnego, unici, „Studia Theologica Varsaviensia" 1997, t. 35, nr 1, ss. 143-170.

Litwin H., Chwała Pólnocy. Rzeczpospolita w polityce Stolicy Apostolskiej w pierwszej połowie XVII wieku (1598-1648), Lublin, Wydawnictwo KUL, 2013, 332 ss.

Kruppa T., Pápai csapatok Magyarországon (1595-1597, 1601), Budapest - Roma, The Publishing House "Gondolat", 2020, 290. ss

Marshall P., The Mercurial Emperor. The Magic Circle of Rudolf II in Renaissance Prague, London, Pimlico, 2007, 276 ss.

Milewski D., Między patronatem a wspótpraca - relacje Jana Zamoyskiego i hospodara mołdawskiego Jeremiego Mohyty (1595-1605), „Wieki Stare i Nowe” 2012, tom specjalny, ss. 11-31.

Niederkorn J.P., Die europäischen Mächte und der „Lange Türkenkrieg“ Kaiser Rudolfs II. (1593-1606), Wien, Verlag der Österreichischen Akademie der Wissenschaften, 1993, 559 ss.

Panov V., Tři moskevské mise Mikuláše Varkoče 1589-1594 ve světle diplomatického rituálu Ruska, „Opera historica. Časopis pro dějiny raného novověku” 2019, t. 20, nr 1, ss. 7-19.

Pastor L., Storia dei papi, t. 10, Roma, Desclée \& C.Editori Pontifici, 1928, 687 ss.

Pastor L., Storia dei papi, t. 11, Roma, Desclée \& C.Editori Pontifici, 1929, 842 ss.

Pausz C., Das Krim-Khanat und der Aufstieg des Zaporoger Kosakentums. Erich Lassotas Mission im diplomatischen Kontext, „Österreichische Zeitschrift für Geschichtswissenschaften" 2017, t. 28, nr 1, ss. 14-40.

Pierling P., Papes et Tsars (1547-1597). D'Après des Documents Nouveaux, Paris, Retaux-Bray, 1890, 514 ss.

Pierling P., La Russie et le Saint-Siège. Études diplomatiques, t. 2, Paris, Plon-Nouritt et C-ie, Imprimeurs-Editeurs, 1897, 416 ss.

Pignatti F., Komulović Alexandar, [w:] Dizionario Biografico degli Italiani, t. 62, Rome, Istituto dell'Enciclopedia Italiana, 2004, ss. 757-759.

Polčin S., Une tentative d'Union au XVIe siècle. La Mission réligieuse du Père Antoine Possevin SJ en Moscovie (1581-82), Roma, Pont. Institutum Orientalium Studiorum, 1957, 141 ss.

Press V., The Habsburg Court as Center of the Imperial Government, „The Journal of Modern History" 1986, t. 58, ss. 23-45.

Santich J.J., Missio Moscovitica. The Role of the Jesuits in the Westernization of Russia, 1582-1869, New York, Peter Lang, 1995, 255 ss. 
Sas J., Uktady o Lige przeciw Turkom za Zygmunta III, „Przegląd Powszechny” 1899 , t. 63 , ss. $54-71$.

Setton K.M., Venice, Austria, and the Turks in the Seventeenth Century, Philadelphia, American Philosophical Society, 1991, 502 ss.

Smołucha J., Legacja kardynała Enrica Caetaniego do Rzeczypospolitej w latach 1596-1597 w świetle instrukcji generalnych z czasów pontyfikatu papieża Klemensa VIII, [w:] Sztuka roztropności. Dyplomacja Stolicy Apostolskiej wobec Rzeczypospolitej, Europy i świata w epoce nowożytnej i XX wieku. Zbiór studiów, red. K. Ożóg, R. Skowron, Kraków, Polska Akademia Umiejętności, 2020, ss. 91-105

Smołucha J., Uwagi na temat kwestii tureckiej $w$ działalności dyplomatycznej $i$ naukowej ojca Antonia Possevino, [w:] Antonio Possevino SJ (1533-1611). Życie i dzieło na tle epoki, red. D. Quirini-Popławska, Kraków, WAM, 2012, ss. 545562.

Szilas L., Alfonso Carrillo jezsuita Erdélyben (1591-1599), Budapest, METEM, 2001, 159 ss.

Trstenjak A., Alessandro Komulovic S.I., 1548-1608. Profilo, „Archivum Historicum Societatis Iesu" 1989, t. 58, ss. 43-86.

Trstenjak T., Aleksandar Komulović kao mogući uzor Jurju Križaniću u politici i crkvenom jedinstvu, ,Zbornik Odsjeka za povijesne znanosti Zavoda za povijesne i društvene znanosti Hrvatske akademije znanosti i umjetnosti” 1986, t. 14, ss. 285-302.

Velez K., The Miraculous Flying House of Loreto. Spreading Catholicism in the Early Modern World, Princeton, Princeton University Press, 2019, 312 ss.

Zlatar Z., Our Kingdom Come. The Counter-Reformation, the Republic of Dubrovnik, and the Liberation of the Balkan Slavs, New York, Columbia University Press, 1992, 464 ss.

Żelewski R., Jazłowiecki Mikołaj h. Abdank, [w:] Polski słownik biograficzny, t. 11, Wrocław, Wydawnictwo Polskiej Akademii Nauk, 1964-1965, ss. 124-126.

\section{References}

Primary sources

Archivio Apostolico Vaticano, Segr. Stato, Nunziature Diverse 273.

Biblioteca Apostolica Vaticana, Urb. lat. 866

Biblioteca Apostolica Vaticana, Urb. lat. 1057.

Biblioteca Apostolica Vaticana, Urb. lat. 1064. 
Biblioteca Apostolica Vaticana, Vat. Lat. 5440.

Biblioteca Apostolica Vaticana, Vat. lat.13460.

Fermendžin E. (Ed.), Acta Bosnae potissimum ecclesiastica cum insertis editorum documentorum regestis ab anno 925 usque ad annum 1752, Zagreb, Taberna libraria, 1892, $620 \mathrm{pp}$.

Fermendžin E., Prilozi $k$ poznavanju diplomatskoga poslanstva Aleksandra Komulovića medju Slovene od godine 1593 do 1597, "Starine" 1918, vol. 36, pp. 7-30.

Jaitner K. (Ed.), Die Hauptinstruktionen Clemens'VIII. für die Nuntien und Legaten an den europäischen Fürstenhöfen (1592-1605), vol. 1, Tübingen, M. Niemeyer, 1984, 1329 pp.

Jaitner K. (Ed.), Die Hauptinstruktionen Clemens 'VIII. für die Nuntien und Legaten an den europäischen Fürstenhöfen (1592-1605), vol. 2, Tübingen, M. Niemeyer, 1984, 1040 pp.

Mosconi N., La nunziatura di Praga di Cesare Speciano (1592-1598): nelle carte inedite vaticane e ambrosiane, vol. 3, Brescia, Morcelliana, 1966, 282 pp.

Pierling P., Novi izvori o L. Komuloviću, "Starine" 1884, vol. 16, pp. 209-251.

Pierling P., Rački F., L. Komolovica izvještaj i listovi o poslanstvo njegovu u Torsku, Erdelj, Moldavsku i Poljsku "Starine" 1882, vol. 14, pp. 83-124.

Rajnolda Hejdensztejna, sekretarza królewskiego, Dzieje Polski od śmierci Zygmunta Augusta do roku 1594, trans. M. Gliszczyński, vol. 2, Petersburg, B.M. Wolff, $1857,484 \mathrm{pp}$.

Theiner A. (Ed.), Vetera monumenta Poloniae et Lithuaniae gentiumque finitimarum historiam illustrantia, vol. 3, Rome, Typis Vaticanis, 1863, 771 pp.

Theiner A. (Ed.), Vetera monumenta Slavorum Meridionalium historiam illustrantia, vol. 2, Zagreb, Academia Scientiarum et Artium Slavorum Meridionalium, $1875,346 \mathrm{pp}$.

Turgenev A.J. (Ed.), Historica Russiae Monumenta ex antiquis exterarum gentium archivis et bibliothecis deprompta, vol. 2, Petropoli, Typis Eduardi Pratzi, 1842, $449 \mathrm{pp}$.

Welykyj A.G. (Ed.), Documenta Pontificum Romanorum historiam Ucrainae illustrantia (1075-1953), vol. 1, Rome, PP. Basiliani, 1953, 686 pp.

Secondary sources

Bartl P., „Marciare verso Costantinopoli” - Zur Türkenpolitik Klemens' VIII ["Marciare verso Costantinopoli" - On Clement VIII's Turkish Policy], "Saeculum" 1969, vol. 20, pp. 44-56. 
BarwickaA., Rzeczpospolita wplanach dyplomacjipapieskieji habsburskiej wokresie wojny austriacko-tureckiej 1593-1606 [Polish-Lithuanian Commonwealth in the Plans of Papal and Habsburg Diplomacy During the Austro-Turkish War of 1593-1606], [in:] Polska wobec wielkich konfliktów w Europie nowożytnej [Poland in the Face of the Great Conflicts in Modern Europe], R. Skowron (Ed.), Kraków, Societas Vistulana, 2009, pp. 297-307.

Coltrinari F., Loreto as an Illyrian Shrine. The Artistic Heritage of the Illyrian Confraternities and College in Loreto and Recanati, "Confraternitas" 2016, vol. 27, no. 1-2, pp. 46-61.

Fine J.V.A., When Ethnicity Did Not Matter in the Balkans, Ann Arbor, University of Michigan Press, 2006, 652 pp.

Gregorowicz D., Tiara w grze o koronę. Stolica Apostolska wobec wolnych elekcji w Rzeczypospolitej Obojga narodów w drugiej polowie XVI wieku [Tiara in the Game for the Crown. The Holy See Towards Free Elections in the Polish-Lithuanian Commonwealth in the Second Half of the $16^{\text {th }}$ Century], Kraków, Polska Akademia Umiejętności, 2019, 496 pp.

Gudelj J., San Girolamo dei Croati a Roma. Gli Schiavoni e il cantiere sistino [San Girolamo dei Croati in Rome. The Schiavoni and the Sistine Building Site], [in:] Identitŕ e rappresentazione. Le chiese nazionali a Roma, 1450-1650 [Identity and Representation. The National Churches in Rome, 1450-1650], A. Koller,

S. Kubersky-Piredda (Eds.), Rome, Campisano Editore, 2015, pp. 297-325.

Gudelj J., The Hospital and Church of the Schiavoni/Illyrian Confraternity in Early Modern Rome, "Confraternitas" 2016, vol. 27, no. 1-2, pp. 5-29.

Halecki O, Od unii florenckiej do unii brzeskiej [From the Union of Florence to the Union of Brest], vol. 2, trans. A. Niklewicz, Lublin, Instytut Europy ŚrodkowoWschodniej [Institute for Central and Eastern Europe], 1997, 344 pp.

Halecki O., The Renaissance Origin of Panslavism, "The Polish Review" 1958, vol. 3, no. $1 / 2$, pp. 7-19.

Jačov M., I Balcani tra impero ottomano e potenze europee (sec. XVI e XVII). Il ruolo della diplomazia pontificia [The Balkans Between the Ottoman Empire and European Powers (16 ${ }^{\text {th }}$ and $17^{\text {th }}$ Centuries). The Role of Papal Diplomacy], Cosenza, Periferia, 1997, pp. 280.

Kadić A., Krizanic's Formative Years, [in:] From Croatian Renaissance to Yugoslav Socialism, C.H. Van Schooneveld (Ed.), Hague, De Gruyter Mouton, 1969, pp. 41-73.

Kocowski B., Wyprawa Tatarów na Węry przez Polskę w 1594 r. [The Tatar expedition to Hungary Through Poland in 1594], Lublin, Towarzystwo Naukowe KUL, 1948, $70 \mathrm{pp}$. 
Krasiński J., Unia brzeska: kontekst i treść aktu uniijnego, unici [Union of Brest: Context and Content of the Union Act, Uniates], "Studia Theologica Varsaviensia" 1997, vol. 35, no. 1, pp. 143-170.

Kruppa T., Pápai csapatok Magyarországon (1595-1597, 1601) [Papal Troops in Hungary (1595-1597, 1601)], Budapest - Roma, The Publishing House "Gondolat", 2020, 290 pp.

Litwin H., Chwała Pólnocy. Rzeczpospolita w polityce Stolicy Apostolskiej w pierwszej polowie XVII wieku (1598-1648) [Glory of the North. The Polish-Lithuanian Commonwealth in the Politics of the Holy See in the First Half of the $17^{\text {th }}$ Century (1598-1648)], Lublin, Wydawnictwo KUL, 2013, pp. 332.

Marshall P., The Mercurial Emperor. The Magic Circle of Rudolf II in Renaissance Prague, London, Pimlico, 2007, 276 pp.

Milewski D., Między patronatem a wspótpracq - relacje Jana Zamoyskiego i hospodara motdawskiego Jeremiego Mohyly (1595-1605) [Between Patronage and Cooperation - Reports from Jan Zamoyski and Jeremi Mohyła, a Moldavian hospodar (1595-1605)], "Wieki Stare i Nowe" [The Old and the New Ages] 2012, special volume, pp. 11-31.

Niederkorn J.P., Die europäischen Mächte und der "Lange Türkenkrieg” Kaiser Rudolfs II. (1593-1606) [The European Powers and the "Long Turkish War" of Emperor Rudolf II (1593-1606)], Wien, Verlag der Österreichischen Akademie der Wissenschaften, 1993, 559 pp.

Panov V., Tři moskevské mise Mikuláše Varkoče 1589-1594 ve světle diplomatického rituálu Ruska [Three Missions of Niclas Warkotsch to Moscow in 1589-1594 in the Light of Russian Diplomatic Ritual], "Opera historica. časopis pro dějiny raného novověku" [Opera historica. Journal of Early Modern History] 2019, vol. 20, no. 1, pp. 7-19.

Pastor L., Storia dei papi [History of the Popes], vol. 10, Rome, Desclée \& C.Editori Pontifici, 1928, 687 pp.

Pastor L., Storia dei papi [History of the Popes], vol. 11, Rome, Desclée \& C.Editori Pontifici, 1929, 842 pp.

Pausz C., Das Krim-Khanat und der Aufstieg des Zaporoger Kosakentums. Erich Lassotas Mission im diplomatischen Kontext [The Crimean Khanate and the Rise of Zaporog Cossackdom. Erich Lassota's Mission in the Diplomatic Context], "Österreichische Zeitschrift für Geschichtswissenschaften” 2017, vol. 28, no. 1, pp. 14-40.

Pierling P., Papes et Tsars (1547-1597). D'Après des Documents Nouveaux [Popes and Tsars (1547-1597). From New Documents], Paris, Retaux-Bray, 1890, $514 \mathrm{pp}$. 
Pierling P., La Russie et le Saint-Siège. Études diplomatiques [Russia and the Holy See. Diplomatic studies], vol. 2, Paris, Plon-Nouritt et C-ie, Imprimeurs-Editeurs, $1897,416 \mathrm{pp}$.

Pignatti F., Komulović Alexandar [Komulović Aleksandar], [in:] Dizionario Biografico degli Italiani [Biographical Dictionary of Italians], vol. 62, Rome, Istituto dell'Enciclopedia Italiana, 2004, pp. 757-759.

Polčin S., Une tentative d'Union au XVIe siècle. La Mission réligieuse du Père Antoine Possevin SJ en Moscovie (1581-82) [An Attempt of Union in the $16^{\text {th }}$ Century. The Religious Mission of Father Antonio Possevino SJ to Muscovy (1581-82)], Rome, Pont. Institutum Orientalium Studiorum, 1957, 141 pp.

Press V., The Habsburg Court as Center of the Imperial Government, "The Journal of Modern History" 1986, vol. 58, pp. 23-45.

Santich J.J., Missio Moscovitica. The Role of the Jesuits in the Westernization of Russia, 1582-1869, New York, Peter Lang, 1995, 255 pp.

Sas J., Uktady o Lige przeciw Turkom za Zygmunta III [The Treaty of the League Against the Turks Under Sigismund III], "Przegląd Powszechny" [The Universal Review] 1899, vol. 63, pp. 54-71.

Setton K.M., Venice, Austria, and the Turks in the Seventeenth Century, Philadelphia, American Philosophical Society, 1991, 502 pp.

Smołucha J., Legacja kardynała Enrica Caetaniego do Rzeczypospolitej w latach 1596-1597 w świetle instrukcji generalnych z czasów pontyfikatu papieża Klemensa VIII [Legation of Cardinal Enrico Caetani to the Polish-Lithuanian Commonwealth in 1596-1597 in the Light of General Instructions from the Pontificate of Pope Clement VIII], [in:] Sztuka roztropności. Dyplomacja Stolicy Apostolskiej wobec Rzeczypospolitej, Europy i świata w epoce nowożytnej i XX wieku. Zbiór studiów [The Art of Prudence. Diplomacy of the Holy See towards the Polish-Lithuanian Commonwealth, Europe and the World in the Modern Era and the 20th Century. A Collection of Studies], K. Ożóg, R. Skowron (Eds.), Kraków, Polska Akademia Umiejętności, 2020, pp. 91-105

Smołucha J., Uwagi na temat kwestii tureckiej $w$ działalności dyplomatycznej $i$ naukowej ojca Antonia Possevino, [Notes on the Turkish Diplomatic and Scientific Activities of Antonio Possevino], [in:] Antonio Possevino SJ (1533-1611). Życie i dzieło na tle epoki [Antonio Possevino SJ (1533-1611). Life and Work Against the Background of the Epoch], D. Quirini-Popławska (Ed.), Kraków, Wydawnictwo WAM [WAM Publishing House], 2012, pp. 545-562.

Szilas L., Alfonso Carrillo jezsuita Erdélyben (1591-1599) [Jesuit Alfonso Carrillo in Transylvania (1591-1599)], Budapest, METEM, 2001, 159 pp. 
Trstenjak A., Alessandro Komulovic S.I., 1548-1608. Profilo biografico [Alexander Komulovic S.I., 1548-1608. Biographical profile], "Archivum Historicum Societatis Iesu" [Historical Archive of the Society of Jesus] 1989, no. 58, pp. 43-86.

Trstenjak T., Aleksandar Komulović kao mogući uzor Jurju Križaniću u politici i crkvenom jedinstvu [Aleksandar Komulović as a Possible Model for Juraj Križanić in the Sphere of the Politics and of the Unity of the Church], "Zbornik Odsjeka za povijesne znanosti Zavoda za povijesne i društvene znanosti Hrvatske akademije znanosti i umjetnosti" [Papers and Proceedings of the Department of Historical Research of the Institute of Historical and Social Research of Croatian Academy of Sciences and Arts] 1986, vol. 14, pp. 285-302.

Velez K., The Miraculous Flying House of Loreto: Spreading Catholicism in the Early Modern World, Princeton, Princeton University Press, 2019, 312 pp.

Zlatar Z., Our Kingdom Come. The Counter-Reformation, the Republic of Dubrovnik, and the Liberation of the Balkan Slavs, New York, Columbia University Press, 1992, 464 pp.

Żelewski R., Jazłowiecki Mikołaj, Abdank coat of arms, [in:] Polski słownik biograficzny [Polish Biographical Dictionary], vol. 11, Wrocław, Wydawnictwo Polskiej Akademii Nauk, 1964-1965, pp. 124-126. 
